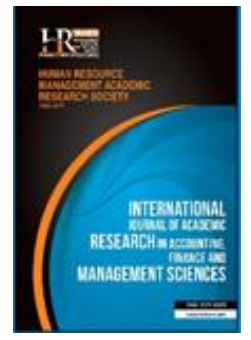

International Journal of Academic Research in Accounting, Finance and Management Sciences

Vol. 9, No.3, July 2019, pp. 264-273

E-ISSN: 2225-8329, P-ISSN: 2308-0337

(C) 2019 HRMARS

www.hrmars.com

To cite this article: Mutalib, F. A., Jaafar, H. (2019). Segment Reporting Practices and Determinants: Evidence from

Malaysian Public Listed Companies, International Journal of Academic Research in Accounting, Finance and

Management Sciences 9 (3): 264-273

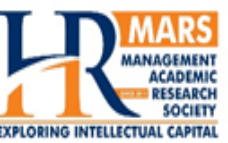

http://dx.doi.org/10.6007/IJARAFMS/v9-i3/6456 (DOI: 10.6007/IJARAFMS/v9-i3/6456)

\title{
Segment Reporting Practices and Determinants: Evidence from Malaysian Public Listed Companies
}

\author{
Farah Abd Mutalib ${ }^{1}$, Hartini Jaafar ${ }^{2}$ \\ ${ }^{1,2}$ Faculty of Management and Economics, Universiti Pendidikan Sultan Idris, Malaysia \\ ${ }^{2}$ E-mail: hartini@fpe.upsi.edu.my (Corresponding author)
}

\begin{abstract}
This study aims to examine the extent and variety of operating segment disclosure among Malaysian public listed companies following the adoption of a new standard MFRS 8 Operating Segment. It further investigates the associations between firm characteristics (firm size, profitability and industrial membership) and the level of compliance to MFRS 8. Using content analysis on a final sample of 97 public listed firms on Bursa Malaysia, the results show that the average level of disclosure on operating segment is $73 \%$ and that the most reported items are both profit and loss, and external revenue at $8.56 \%$ respectively. Meanwhile, the highest segmental information disclosure variety is found to be 11 out of 16 items with only 20.62\% firms found to comply with such disclosure variety. The results also indicate that industrial membership affects the level of segmental reporting compliance. The research outcomes serve as a valuable benchmark for comparison with other emerging nations in terms of the level of compliance to segment reporting practices and provide more insights into the interactions between the level of compliance and firm characteristics.

Key words

Segment reporting, MFRS 8, IFRS 8

Received: 22 Sep $2019 \quad$ (C) The Authors 2019

Revised: 05 Oct 2019 Published by Human Resource Management Academic Research Society (www.hrmars.com)

Accepted: $\quad 08$ Oct 2019 This article is published under the Creative Commons Attribution (CC BY 4.0) license. Anyone may Published Online: 29 Oct $2019 \quad$ reproduce, distribute, translate and create derivative works of this article (for both commercial and non-commercial purposes), subject to full attribution to the original publication and authors. The full terms of this license may be seen at: http://creativecommons.org/licences/by/4.0/legalcode
\end{abstract}

\section{Introduction}

The globalisation of accounting system and diversification of business activities by firms around the world has increased the need for segment reporting. The underpinning objective behind segment reporting is to disclose financial information useful for corporate managers, creditors, analysts, investors, government agencies and other users of financial statement in order to facilitate them in making informed decisions. Despite segment reporting being a controversial and highly debated issue due to the nature of the information disclosed being regarded as commercially sensitive (Parker and Sauer, 2009), the benefits are also being consistently highlighted. Segment disclosures, for example can enhance security valuation (Tse, 1989), facilitate investors to make informed investment decisions (Herrmann and Thomas, 2000), assess and predict firm performance (Knutson, 1993) and improve earnings forecasts (Hope et al, 2009; Kang and Gray, 2013). Managers, however, have incentives to report fewer segments externally rather than are actually present within a company to conceal industry diversity (Berger and Ofek, 1995) and to minimise proprietary costs (Hayes and Lundholm, 1996; Botosan and Stanford, 2005) as well as agency costs (Berger and Hann, 2007).

The importance of segment information to both financial analysts and general users of financial reports has been recognised by standard setters around the world (Kang and Gray, 2013), leading to 
numerous efforts being carried out to develop and revise financial reporting standards regarding segment disclosures. One of the most significant efforts taken is where the standard setters are moving towards requiring firms to provide segment disclosure according to their internal reporting structure (known as the management approach) in response to criticisms that firms were aggregating segments for external reporting purposes (Bugeja et al., 2015). Internationally, the effort to further improve the quality of financial information were implemented with the introduction of IFRS 8 Operating Segments by the International Accounting Standards Board (IASB) in 2006 that was aligned closely to the Financial Accounting Standards Board's (FASB) Statement of Financial Accounting Standards (SFAS) 131 Disclosures about Segments of an Enterprise and Related Information. The standard requires general and entity wide disclosure about the enterprise, including information about products and service, geographical areas including country of domicile and individual foreign countries (if material), major customers and factors used to identify an entity's reportable segment. Such disclosure is required even if an entity only has one segment and the requirements to disclose segment information are particularly relevant for public listed companies.

Nonetheless, the introduction of IFRS 8 did not receive positive overall market acceptance and was faced by some controversial challenges. This is because IFRS 8 introduced material changes in the identification, measurement and disclosure of segment information, resulting in substantial changes to segment reporting practices (IASB, 2006). Concerns have been raised regarding the content of the proposed standard, particularly the movement to pure management approach that provides considerable managerial discretion, allowing the reporting of non-IFRS segment measures, a potential decrease in in geographical segment disclosures, and elimination of the requirement to disclose segment liabilities (Susela Devi, 2007; Crawford et al., 2012; Nichols et al., 2012). In Malaysia, MFRS 8 Operating Segments (an equivalent standard to IFRS 8) was issued by the MASB and became effective in 2012 to replace FRS 114 Segment Reporting. Following the controversial response on the adoption of management approach under the new standard, therefore this study aims to examine the extent and variety of operating segment disclosure among Malaysian public listed companies. It also seeks to investigate whether firm characteristics affect the level of compliance to segment reporting following the adoption of MFRS 8 .

\section{Literature review}

Segment information is seen as a means to provide decision useful information and that management approach will serve as a channel that will ensure the sustenance of free flow of segregated information leading to mitigating information asymmetry that may arise as a result of agency conflicts. According to European Commission (2007) the adoption of this approach will contribute to the increase of the relevance and usefulness of the segment information by allowing users to view the firm through the eyes of management. This should promote better consistency between segregated information contained in financial statements and the information presented in the management report. In general, it is argued internationally that the move towards management approach will improve the quality of financial reporting (Devi, 2007).

In the history of standard settings in Malaysia, segment reporting has presented difficulties to the accounting professions and firms in the early days of its adoption. Segment reporting standard based on International Accounting Standards (IAS) 14 Segment Reporting was first introduced in 1985 and early studies of compliance such as Devi and Veerinderjeet (1992) argued that the enforcement of the new accounting standard was an issue. Specifically they revealed a reluctance to comply on the part of preparers on the grounds that the segment information undermined their competitive adoption of extended disclosure practices. In 1997, the IASB issued IAS 14, which was essentially similar to SFAS 131 issued by the FASB. However, IAS 14 which became effective for periods beginning on or after 1 July 1998 was not adopted in Malaysia and the Malaysian Accounting Standards Board (MASB) issued a Malaysian approved accounting standard MASB 22 Segment Reporting in 2002 (later renamed as FRS 114 in 2006). The standard incorporate the appropriation of two-tier segmentation with either the geographical segment or the business segment as the pre-eminent basis of segment reporting (primary segment) and the other as secondary segment, differential information disclosure for primary segment (full disclosure) and secondary 
segment (less disclosure), constant use of accounting policies across segments and standardized measure of segment results across companies.

In the late 2006, the IASB issued IFRS 8 that replaced IAS 14 and aligned segment reporting with the requirements of SFAS 131. IFRS 8 does not define segments as business or geographical segment, rather it defines operating segments as business activities that may earn revenues or incur expenses. These operating results are regularly reviewed by the Chief Operating Decision Maker (CODM) and for which discrete financial information is available, known as the management approach. In the spirit of accounting standards harmonisation, the MASB issued MFRS 8 in November 2011 which is in accordance with Malaysia's plans to merge with the IFRS by 1 January 2012. The standard then became effective on 1 January 2012 for all annual firm periods. Unlike FRS 114, the adoption of MFRS 8 was mirrored as a groundbreaking standard, as it represented the MFRS's first effort to allow users of financial statements to review firm operations through the eyes of a management. However, the shift from a two-tier approach to a management approach has created a difficult situation for companies in disclosing its information to standardize with the new standards adopted. The adoption of the new standard has also created a few crises where there were a decline and inconsistencies in the number of items disclosed in the reportable segment and the number of claims by firms to operate in a single segment (Johari, 2017). Besides that, there were serious issues in the quality of financial report as the practice of non-disclosure of segment reporting by Malaysian firms were not strictly standardized and certain cases shows that firms can choose whether to provide or not their segment information when corresponding competitors provide them (Benjamin et al., 2010).

In other related international studies, Altintas (2010) for instance, examined the impact of changing to IFRS 8 on Turkish listed companies and found that the most important challenge brought by IFRS 8 is the 'management approach' in segment reporting, which requires exposure of internal information used in decision making by managers. However, the findings further suggested that changing to IFRS 8 did not cause significant changes in segments reported and segmental information provided. Kang and Gray (2013) examined changes in segment reporting in Australia following the adoption of Australian Accounting Standards Board (AASB) 8 Operating Segments (the equivalent of IFRS 8) and found out that the number of reportable segments and the extent of disclosure have increased following the new standard adoption. Based on a sample of the top 200 companies listed on the Australian Stock Exchange the results indicated no discernible change to the identification of reportable segments. For example, most companies simply reliable their primary segments referring to its business and geographical segments as operating segments and report essentially the same segment information when identifying operating segments under AASB 8 . The findings however revealed a significant increase in the number of reportable segments, primarily for business segments, and the extent of disclosure on descriptions and related information on other segments. Lucchese and Di Carlo (2016) found that based on a sample of Italian listed companies, the new standard did not lead to relevant changes in the segment disclosures as previously stated under IAS 14R. They further noted that the management approach, introduced under IFRS 8, seems to be in contrast with the general evaluation criteria used in the IAS/IFRSs financial reporting model, oriented to provide the users information reliable, verifiable and objective, thus demonstrating inconsistency with the expectations of the IASB.

While the effects of the preceding accounting standard for segment reporting, FRS 114, have been examined by some Malaysian studies (see for example Wan Nordin et al., 2005; Benjamin et al., 2010), the impact of MFRS 8 adoption has yet to be investigated. Therefore, the primary objective of this study is to examine empirically the impact of MFRS 8 adoption on segment reporting practices in Malaysia. Besides, this study will also provide further insights on the effect of firm characteristics on the level of operating segment disclosure.

\subsection{Determinants of segmental reporting}

Past empirical studies have investigated the level of voluntary disclosures and the determinants of extensiveness of segment disclosures considering its relationship with specific firm factors such as firm size, profitability, industrial membership board composition, financial leverage, audit firm size and firm development rate to clarify the shifting level of disclosures. Bradbury (1992) analysed companies in New 
Zealand and showed that the decision to publish information by segment is positively influenced by company size and level of indebtedness. McKinnon and Dalimunthe (1993) showed that for Australian companies, the shareholding structure, the size and the sector to which the company belongs are related to decisions to disclose information by segment. The presence of a significant positive relationship between segment disclosure and firm size was likewise affirmed by Ahmed and Courtis (1999). Meanwhile, a study in Malaysia by Chow and Devi (2001) also indicated that firm size is positively related with segment disclosure. This is because larger firms are able to incur more costs information on production and distribution. Hence, they are likely to be more informative and pay more attention in improving its quality disclosure because of their financial resources that enables them to expand the disclosure compared to smaller firms. Incurred costs resulting from competitive harm is also affordable for larger firms compared to smaller firms (Nasir and Abdullah, 2004). Thus, it can be concluded that as a firm develops in size, it is very highly likely to operate in a more extensive scope of business activities and geographical regions. Thus, there will be high potential outcomes on the increasing reported segments consolidating various operating unit.

Besides firm size, various examinations have additionally been done to explore the connection between financial performance which is the firms' profit and level of segmental reporting. The argument is that in order to maintain a strategic distance from conceivable contribution of rivals in business activities or geographical areas, a company prefers to disclose a segment that conveys less economic information where a company is doing well. According to Troberg et al., (2010), it is beneficial for highly lucrative companies to inform the capital markets about the segments that contribute substantially to the overall performance, and these benefits outweigh the disclosure costs. Thus, these companies tend to retain less information to avoid problems arising from information asymmetries. Meanwhile, this statement is in contrast to e Souza et al. (2016) who found no significant results for profitability indicating that these factors do not influence such disclosure.

Accounting approaches and practices may fluctuate as per industry and along these lines, the disclosure practices would accordingly be different across businesses. A high degree of industry concentration is likely to discourage the disclosure of confidential information because the costs of disclosure begin to exceed its benefits. The level of competition in the market acts as a disciplining factor, a type of force that limits the presentation of inaccurate disclosures and the concealment of accounting information by companies (Balakrishnan and Cohen, 2011). Harris (1998) argued that the higher the industry concentration, the greater the fear of disclosing strategic information, and companies in low competitive environments prevent disclosures about segments with the aim of protecting their abnormal profits. Firms in a single industry may pressure disclosure items which are viewed as imperative yet may be unessential to another industry. Likewise, Cooke (1991) proposed that there might be reasons why few enterprises may disclose more than others, in view of the temporary bandwagon impact, which if there is one prevailing firm in an industry which has large amounts of disclosure level, this would empower more disclosure by different firms in a similar industry. Besides that, Watson et al. (2002) contended that in view of the signalling theory, firms may flag to demonstrate that they are following with industry's best practices. Thus, industrial membership is also posited to have an effect on the level of segment information disclosure in this study.

\section{Methodology of research}

The sample used in this study was selected among the top 100 publicly listed firms by market capitalization from all industrial sectors out of the total population of 800 firms listed in the Bursa Malaysia Main Board as at 31 December 2016. This study analysed only public listed firms because these firms are required to prepare their financial statements and disclosure notes in accordance with the MFRS. These top 100 firms were chosen based on two primary reasons. First, since these firms represent the largest firms in the industries, thus it is expected that there is greater tendency that they would voluntarily comply earlier to the requirements of MFRS 8 compared to their counterparts. According to Morris et al. (2012), companies with bigger profit are likely to disclose more information so that investors can evaluate better the integrity of their reported earnings and thus encourage their voluntary in disclosing their reporting segment. Secondly, smaller firms are rarely to carry out their business activities in more than one segment, be it operational or geographic. As such, segment reporting is not applicable to these firms as to compare 
to larger firms. However, some annual reports are not readily available thus companies with unavailable data were removed from the sample due to lack of detailed information about operating segments in their annual reports. There were three firms in total, leaving a final sample of 97 firms considered for data collection and in running the relevant analysis.

Table 1 shows the frequency of the firms' distribution according to various industries among the 97 sample firms chosen. The highest number of industry involved in disclosing information regarding operating segment is from trading-services sector with a number of 34 companies (35.05\%) that complied with the rule of MFRS 8 . This then is followed by finance sector with 15 companies (15.46\%), and a number of 11 firms $(11.34 \%)$ for both consumer and industrial products. Next, there are 9 firms $(9.28 \%)$ from the property industry and a group of 5 firms (5.16\%) from the plantation sector. Finally, for industry with least number of firms that disclosed their segment reporting, it is found to belong to the technology industry with only 1 firm (1.03\%) that complies with MFRS 8.

Table 1. Sample Distribution According to Industry/Sector

\begin{tabular}{|c|c|c|}
\hline Industry & Frequency & Percentage (\%) \\
\hline Aviation & 2 & 2.06 \\
\hline Construction & 3 & 3.09 \\
\hline Consumer Products & 11 & 11.34 \\
\hline Finance & 15 & 15.46 \\
\hline Industrial Products & 11 & 11.35 \\
\hline Infrastructure Project Companies (IPC) & 3 & 3.09 \\
\hline Plantation & 5 & 5.16 \\
\hline Properties & 9 & 9.28 \\
\hline Real Estate Investment Trust (REITS) & 3 & 3.09 \\
\hline Technology & 1 & 1.03 \\
\hline Trading-services & 34 & 35.05 \\
\hline Total & 97 & 100 \\
\hline
\end{tabular}

The sample consists of firms that published their annual reports in 2016 that is five years after the introduction of MFRS 8. This particular year is chosen to examine the difference and how far firms comply with the newly adopted standard. Content analysis is used in this study in which each annual report is analysed manually and scored using disclosure index based on the researcher's developed checklist. Sections analysed in the sample annual reports are significant accounting policy, notes to the accounting consolidated profit and loss account and consolidated balance sheet (operating segment reporting section) as well as chairman's statement regarding the recognition of CODM of every firm. The disclosure checklist is developed based on segmental reporting required stated in the MFRS 8. In order to assess the extent and variety of firms' voluntary segment disclosure and to prevent any issues associated with the weighted disclosure index, the present study have applied the un-weighted disclosure index method. The segment disclosure was measured using dichotomous procedure where if an item was disclosed in the financial statements of a company, a value of 1 was recorded and shall there be no item disclosed, a value of 0 was given. Total item disclosed was then divided by the total possible score for each firm to deliver disclosure compliance with the index.

Additionally, multivariate regression analysis is performed to empirically examine the relationships between the level of compliance and firm characteristics. Firm size and profitability are measured using total assets and total comprehensive income, respectively. Meanwhile, to measure industrial membership, a dummy variable was used where a value of 1 was given if the firm was a trading-service firm and a value of 0 for others which represents

\section{Results}

Table 2 shows the extent of segment disclosure identified in the annual reports for the period chosen. The frequency observed for each item disclosed in the sample firms presents that, the most reported item is both profit and loss and external revenue in which 97 samples disclosed this item $(8.56 \%$ of the total item disclosed). Next, the second most reported item are the inter-segment revenue and the 
information on products and services which both item was disclosed by 94 firms $(8.3 \%$ of the total disclosed). Besides that, sitting on the third rank, income tax was disclosed by 92 firms with the percentage of $8.12 \%$ of the total disclosed item, followed by 89 firms that reports total assets in their segmental reporting (7.86\%).

Table 2. The Extent of Disclosure for Operating Segment

\begin{tabular}{clccc}
\hline No & Item & Disclosure & Percentage (\%) & Rank \\
\hline 1 & Profit and Loss & 97 & 8.56 & 1 \\
2 & Total Assets & 89 & 7.86 & 4 \\
3 & Non-Current Assets & 62 & 5.47 & 6 \\
4 & Total Liabilities & 87 & 7.67 & 5 \\
5 & External Revenue & 97 & 8.56 & 1 \\
6 & Inter-Segment Revenue & 94 & 8.30 & 2 \\
7 & Interest Revenue & 51 & 4.50 & 8 \\
8 & Interest Expenses & 13 & 1.15 & 12 \\
9 & Depreciation and Amortization & 87 & 7.68 & 5 \\
10 & Interest by Equity & 54 & 4.77 & 7 \\
11 & Income Tax & 92 & 8.12 & 3 \\
12 & Other Non-Cash Expenses & 42 & 3.71 & 10 \\
13 & Investment in Equity & 41 & 3.61 & 11 \\
14 & Entity Wide Disclosure: Information on Major Customer & 46 & 4.06 & 9 \\
15 & Entity Wide Disclosure: Information on Products and Services & 94 & 8.30 & 2 \\
16 & Entity Wide Disclosure: Information on Geographical Areas & 87 & $\mathbf{7 1}$ & 5 \\
\hline
\end{tabular}

On the other hand, the minimum number of item disclosed is from interest expense $(1.15 \%)$ with a limited number of 13 firms adopt the standard. Investment in equity (3.61\%) and other non-cash expense (3.71\%) are reported by 41 and 42 firms respectively. These represents the least reported items in the firms' annual reports and this may be due to the sensitivity of such information to be publicly announced. The total items reported are a total of 1133 from the sample of 97 firms. As for the Entity-Wide information, products and services are the most reported item reported in the segmental reporting, which is the highlight of this standard. Meanwhile the disclosure of major customer was least recorded by firms with a number of only 46 firms comply to it. Overall, the mean level for voluntary disclosure is considered high with $73 \%$ firms comply with the standard in disclosing information for operating segment.

Table 3 further illustrates the number of varieties in terms of items disclosed by the sample firms. It can be seen that out of 97 firms, a majority of the sample firm (20.62\%) disclosed 11 out of the total 16 items. Next $16.49 \%$ of the sample also managed to disclose of 12 items in their segment reporting followed by $12.38 \%$ disclosing 13 items according to MFRS 8 in their annual report. The results also suggested that only 4 firms (4.12\%) disclosed all 16 items in accordance to the standards. Meanwhile, only 2 firms have the lowest number of items disclosed as per mentioned in the MFRS 8. These firms only comply to 5 and 6 items (1.03\% of the sample) respectively in their segmental report.

Table 3. Number of Segment Items (Varieties) Reported by Firms

\begin{tabular}{ccc}
\hline Items Disclosed & No. of Firms & Percentage (\%) \\
\hline 0 & 0 & 0 \\
1 & 0 & 0 \\
2 & 0 & 0 \\
3 & 0 & 0 \\
4 & 0 & 0 \\
5 & 1 & 1.03 \\
6 & 1 & 1.03 \\
7 & 3 & 3.09 \\
8 & 4 & 4.12 \\
9 & 6 & 6.19 \\
10 & 11 & 11.34 \\
11 & 20 & 20.62
\end{tabular}




\begin{tabular}{ccc}
\hline Items Disclosed & No. of Firms & Percentage (\%) \\
\hline 12 & 16 & 16.49 \\
13 & 12 & 12.38 \\
14 & 11 & 11.34 \\
15 & 8 & 8.25 \\
16 & 4 & 4.12 \\
\hline Total & $\mathbf{9 7}$ & $\mathbf{1 0 0}$ \\
\hline
\end{tabular}

Meanwhile, Table 4 presents data on how certain firms acknowledge their CODM in each firm. The acknowledgement of the CODM is the key component of segment reporting under MFRS 8 which differs from the previous standard where the decision on operating segment will be regularly reviewed by an entity's CODM as per paragraph 5(b) in the IFRS 8. Although the standard specifies the importance of reviewing segment activities by a CODM, the standard does not highlight that a firm should identify specific position of the CODM. The standard declared that the CODM "is not necessarily a manager with a specific title". Thus, different firms tend to have different disclosure on how it identifies their CODM. Table 4 reports the results on the identification of CODM and its disclosure.

Table 4. Disclosure on the CODM

\begin{tabular}{lcc}
\hline Identification On The CODM & Frequency & Percentage (\%) \\
\hline CEO & 19 & 19.59 \\
CODM & 25 & 25.77 \\
COO & 2 & 2.06 \\
Executive Committee & 9 & 9.28 \\
Management Committee & 11 & 11.34 \\
Managing Director & 10 & 10.31 \\
Board Of Director & 13 & 13.40 \\
Manager & 2 & 2.06 \\
Divisional Directors & 2 & 2.06 \\
Group Executive Board & 1 & 1.03 \\
Management Committee and Board of Directors & 1 & 1.03 \\
President and Group Chief Executive & $\mathbf{2}$ & 2.06 \\
\hline \multicolumn{2}{r}{ Total } & $\mathbf{9 7}$ \\
\hline
\end{tabular}

Based on Table 4, only 25 firms (25.77\%) identified their CODM as the CODM that will review the segmental reporting. These results are somewhat surprising as basic principle of MFRS 8 demands segment disclosures to be frequently reviewed by the CODM even though the requirements to disclose information on CODM is not compulsory under the standard. Apart from that, most of the firms described their CODM as the CEO and firm's board of directors with a number of 19 (19.59\%) and 13 (13.4\%) firms disclose this identification respectively. Meanwhile, there are 3 firms disclose their CODM as the group executive board, management committee and board of directors respectively.

Table 5 shows that there is no significant relationship between the level of compliance to reporting segment and firm size because $(t=0.703, p>0.05)$. This shows that firm size does not influence the level of compliance to reporting segment. This finding is different from the study by Talha and Sallehhuddin (2009) and Souza et al. (2016) who showed that firm size is significant thus affects the primary segment reporting. In addition, Mateescu (2016) in her study showed that the positive relationship between the IFRS 8 compliance list and the firms' size supported the basic inference that bigger firms are usually much more transparent than other firms. This is however, not supported in the current study.

The results also reveal that there is no significant relationship between the level of compliance to reporting segment and profitability $(t=-1.700, p>0.05)$. This shows that profitability does not influence the level of compliance to reporting segment. The result differs from the findings of Nordin et al. (2005) which showed that fully early adopters are significantly larger and are more profitable. Similarly, Ettredge et al. (2006) found that profit significantly influence the level of disclosure since the adoption of management approach that has been employed. This is based on the consistent analysis with their hypothesis which recommends that the use of the 'management approach' to defining segments is related with a more extensive scope of reported segment profit margins. Thus, they stated that if firms 
continuously decide to report segment activities using the business approach, the higher disclosure in profit will not be able to supply investors with additional information and it would be a misfortune to the firm.

Table 5. Determinants of Segment Reporting Compliance

\begin{tabular}{ccc}
\hline Variables & Predicted Sign & Coefficient $t$-statistic \\
\hline \multirow{2}{*}{ Constant } & $+/-$ & 80.858 \\
& & $6.507^{* * *}$ \\
SIZE & + & 0.703 \\
& & 0.278 \\
PROFIT & + & -1.700 \\
& & -0.621 \\
INDUSTRY & + & 7.368 \\
& & $2.409^{* * *}$ \\
\hline N & & 97 \\
Adj. R2 & & 0.046 \\
F-statistic & & $3.186^{* *}$ \\
\hline
\end{tabular}

***Significant at the 1\% level (one-tailed test when the sign is predicted; two-tailed otherwise)

However, the results suggest that there is a significant relationship between the level of compliance to reporting segment and industrial membership $(t=7.368, p<0.001)$. This is in contrast to e Souza et al., (2016) which showed that the characteristics of industry concentration do not have a significant effect on the level of disclosure of information about segments. However, this finding provides support to Talha and Sallehhuddin (2009) in which industrial membership is found to be significantly related to the primary segment selection among companies.

\section{Discussions and Conclusions}

The results of the study show that the disclosure levels in complying with the standards varies among firms, since the act of reporting segmental information is influenced by firms' management purposes and daily business activities. From the results, it appears that public listed firms in Malaysia were still at the edge of not fully practicing the standards and that improvements are needed to encourage firms in complying with MFRS 8. Besides that, the shift of identifying the CODM was still behind the line as more than half of the sample firm turn a blind eye in recognising certain person for that title. The disclosure of this information is crucial to the users of the report such as stakeholders, as the identity of CODM may help them to trace how firms are organized and where key decisions on business operations are being made. Thus, any possibilities of an enforcement mechanisms that could help increase the level of segment disclosure is the point of interest to be discussed based on the results retrieved.

This study also has indirectly provides more insight into Malaysian public listed firm acceptance to the implementation of MFRS 8 and the level of compliance with MFRS 8 especially when taking into account on how firm characteristics could shape the way and manner in which financial is reported. This is essential considering that financial reporting serves as a main guide through which users view the operations of through the management's eyes. Therefore, this study is beneficial for regulators and standard-setting bodies as a valuable reference in improving the quality of the disclosure system and to urge the compliance level among firms. Besides that, studying the incentives of segmental disclosure allows policy-makers to distinguish whether there is a need to enforce obligatory disclosures and reduce the flexibility of reporting requirements to prevent from any malpractice of information-concealing or to strengthen mechanisms in encouraging the information transparency disclosed.

The adoption of MFRS 8 which focuses on the management approach to segment reporting will provide greater opportunity to the users of financial statements in examining the performance from the senior managements' perspective. It will help facilitate the users of financial statements to inquire and examine how the entity is controlled by their senior decision makers. Reporting under MFRS 8 also reduces the cost of preparing the information on reportable segments because the information is already to be used internally by the management and readily available on a timely basis. The shift from a two-tier approach to a management approach requires a lot of changes. Nevertheless, if the process of 
implementation is carefully administered, it will bring many advantages to complying firms. In order to ensure successful adoption of the standard, the Malaysian accounting standard-setters needs to reconsider the obstacles that arise in the process of implementing the discussed MFRS 8.

\section{References}

1. Ahmed, K. \& Courtis, J. K. (1999). Associations between Corporate Characteristics and Disclosure Levels in Annual Reports: A Meta-analysis. British Accounting Review, 31(1), 35-61.

2. Altintas, T. (2010). Switching to IFRS 8 and Its Impact on the Turkish Listed Companies. Dumlupinar University Journal of Social Sciences, 2, 98-107.

3. Balakrishnan, K., \& Cohen, D. A. (2011). Product market competition and financial accounting misreporting. SSRN Working Paper. Retrieved from

http://papers.ssrn.com/sol3/papers.cfm?abstract_id=1927427

4. Benjamin, S. J., Muthaiyah, S., Marathamuthu, M. S., and Murugaiah, U. (2010). A Study of Segment Reporting Practices: A Malaysian Perspective, The Journal of Applied Business Research, 26 (3), 31 -41 .

5. Berger, P., and Hann, R. (2007). Segment Profitability and the Proprietary and Agency Costs of Disclosure, The Accounting Review, 82 (4), 869 - 906.

6. Berger, P., and Ofek, E. (1995). Diversification's Effect on Firm Value, Journal of Financial Economics, 37 (1), $39-65$.

7. Botosan, C,. and Stanford, M. (2005). Managers Motives to Withhold Segment Disclosures and the Effect of SFAS No. 131 on Analyst's Information Environment, The Accounting Review, 80 (3), 751 - 771.

8. Bradbury, M. E. (1992). Voluntary disclosure of financial segment data. Accounting and Finance, 32(1), 15-26.

9. Bugeja, M., Czernkowski, R. and Moran, D. (2015). The Impact of the Management Approach on Segment Reporting, Journal of Business Finance and Accounting, 42 (3) \& (4), $310-366$.

10. Chow, W. L., \& Devi, S. S. (2001). Accounting disclosure practices and firm characteristics: Evidence from Malaysia based on segment information disclosure. Paper presented at the 13th Asia Pacific Conference on International Accounting Issues, Rio De Janeiro, Brazil, 28-31 October.

11. Cooke, T. E. (1991). An Assessment of Voluntary Disclosure in the Annual Reports of Japanese Corporations. International Journal of Accounting, 26(3), 174-189.

12. Crawford, L., Extance, H., Helliar, C. and Power, D. (2012). Operating Segments: The Usefulness of IFRS 8, Institute of Chartered Accountants of Scotland Report, Edinburgh: CG UK.

13. Souza, E. J. A., Neto, A. S., Benedicto, G. C., \& Mendonça. D. J. (2016). Segment Reporting in Brazil: Factors Influencing the Disclosure. International Journal of Business Management and Economic Research, 7(6), 804-816.

14. Ettredge, M. L., Kwon, S. Y., Smith, D. B., \& Stone, M. S. (2006). The effect of SFAS No. 131 on the cross-segment variability of profits reported by multiple segment firms. Review of Accounting Studies, 11(1), 91-117. http://doi.org/10.1007/s11142-006-6397-9

15. European Commission (2007). Endorsement of IFRS 8 Operating Segments Analysis of Potential Effects, European Commission Report. Available online at http://ec.europa.eu/internal_market/ accounting/docs/ifrs8-operatingsegments-report.pdf

16. Harris, M. S. (1998). The Association Competition and Managers' Business Segment Reporting Decisions. Journal of Accounting Research, Spring, 111-128.

17. Hayes, R., and Lundholm, R. (1996). Segment Reporting to the Capital Market in the Presence of a Competitor, Journal of Accounting Research, 34 (2), 261 - 279.

18. Herrmann, D., and Thomas, W. (2000). An Analysis of Segmental Disclosures Under SFAS No. 131 and SFAS No. 14, Accounting Horizons, 14 (3), $287-302$.

19. Hope, O. K., Kang, T., Thomas, W. B., and Vasvari, F. (2009). The Effects of SFAS 131 Geographic Segment Disclosures by US Multinational Companies on the Valuation of Foreign Earnings, Journal of International Business Studies, 40, $421-443$.

20. Johari, J. (2017). Post-implementation of MFRS 8 "Operating Segment" among listed firms in Malaysia. SHS Web of Conferences, 34. 
21. Kang, H. and Gray, S. (2013). Segment Reporting Practices in Australia: Has IFRS 8 Made a Difference? Australian Accounting Review, 23 (3), 232 - 243.

22. Knutson, P. (1993). Financial Reporting in the 1990s and Beyond, The Association for Investment Management and Research. Charlottesville: USA.

23. Lucchese, M. \& Carlo, D. F. (2016). The Impact of IFRS 8 on Segment Disclosure Practice: Panel Evidence from Italy, International Journal of Accounting and Financial Reporting, 6 (1), 96-126.

24. Mateescu, R. (2016). Segment disclosure practices and determinants: Evidence from Romanian listed companies. The International Journal of Management Science and Information Technology, 20, 4051.

25. McKinnon, J. L., \& Dalimunthe, L. (1993). Voluntary disclosure of segment information by Australian diversified companies. Accounting \& Finance, 33(1), 33-50.

26. Morris, R., Susilowati, I., \& Gray, S. (2012). The Impact of IFRS Adoption versus Non- Adoption on Corporate Disclosure Levels in the Asian Region. American Accounting Association Annual Meeting, American Accounting Association, Washington DC, USA, presented at American Accounting Association Annual Meeting, Washington DC, USA, 04-08 August. http://aaahq.org/AM2012/abstract.cfm? submissionID $=3225$

27. Nasir, N. M. \& Abdullah, S. N. (2004). Information Provided by Accrual and Cash Flow Measures in Determining Firms' Performance: Malaysian Evidence, American Journal of Applied Sciences, 1 (2), 64-70.

28. Nichols, N., Street, D., and Cereola, S. (2012). An Analysis of the Impact of Adopting IFRS 8 on the Segment Disclosures of European Blue Chip Companies, Journal of International Accounting, Auditing \& Taxation, 21 (2), $79-105$.

29. Parker, C., and Sauer, D. (2009). Understanding Segment Information, Charter, December, 58 59.

30. Devi, S. (2007). MASB ED 57 - Operating Segments: Is This What Analysts' Want? Accountants Today, October, $56-57$.

31. Devi, S., \& Veerinderjeet, S. (1992). Segmental reporting in Malaysia: Relevance, extent of compliance and disclosure. Akauntan Nasional, 3 \& 4 (April), 12-20.

32. Talha, M., \& Salim, A. S. A. (2009). What prompts firms to choose between business and geographic segments as a primary segment? Managerial Auditing Journal, 25(1), 17-31.

33. Troberg, P., Kinnunen, J., \& Seppänen, H. J. (2010). What drives cross-segment diversity in returns and risks? Evidence from Japanese and US firms. The International Journal of Accounting, 45(1), 44-76.

34. Tse, S. (1989). Attributes of Industry, Industry Segment and Firm-specific Information in Security Valuation, Contemporary Accounting Research, 5 (2), 592 - 614.

35. Nordin, W. H., Noriah, C. A., Asma, N. L. and Hasnah, K. (2005). Determinants of Early Adoption of FRS 114 (Segment Reporting) in Malaysia, Asian Academy of Management Journal, 10 (2), 1 - 20.

36. Watson, A., Shrives, P. \& Marston, C. (2002). Voluntary Disclosure of Accounting Ratios in the U.K. The British Accounting Review, 34(4), 289-313. 